\title{
Panel Regression Models for Paddy (Oryza sativa) Crop Production
}

\author{
Rajarathinam, $\mathbf{A}^{\mathbf{1}}$ and Suba S.S . \\ ${ }^{1,2}$ Department of Statistics, Manonmaniam Sundaranar University, Tirunelveli - 627012 , \\ Tamil Nadu State, India \\ rajarathinam@msuniv.ac.in ${ }^{1}$ and sssuba@gmail.com ${ }^{2}$
}

\begin{abstract}
The present investigation was carried out to study area production trends of Paddy crop grown in different districts of Tamil Nadu state, India during the period 1998-99 to 20102020 based on Panel Regression Model. The statistically most suited Panel Regression model was selected based on Hausman and Wald test. The study variables namely the area under the Paddy crop (AREA) and the production (PRODN) of Paddy crop were found to be stationary at level. Analysis of variance test indicated that district to district crop productions were highly significant. Highest area under the crops and productions were registered in Tiruvarur, Thanjavur etc., Very lowest were registered in Coimbatore and Nilgiris districts. The fixed effect model was found to be suitable to study the trend and this model explains the $87 \%$ of variations in Paddy crop production.
\end{abstract}

Keywords: Panel Regression Model, Least-Squares Dummy Variable, Fixed-Effect Model, Random-Effect Model, Wald Test, Hausman Test.

\section{Introduction}

Over the last few decades, regression modelling has traditionally been employed in agricultural production prediction and classification. For agricultural planning purposes, decision-makers need simple and reliable estimation techniques for crop production prediction. Multiple regressions, Discriminant analysis, factor analysis, principal component analysis, cluster analysis and logistic regression analysis are the most commonly used statistical techniques for the prediction and classification of agricultural-related production. In agricultural production time series data, the problems of multicollinearity, autocorrelation and extreme values are unavoidable. In such complex situations, regression models may not provide accurate predictions. Regression models need to fulfil regression assumptions such as autocorrelation and multiple collinearity between the independent variables, which causes the estimated regression models to be unfit and the estimated parameter values obtained based on these models to be inefficient. In most agricultural practices, crop production is influenced by a great variety of interrelated factors such as autocorrelation, and it is difficult to describe their relationships using conventional methods (Zaefizadahet al., 2011).

In this study, panel data regression model is used to combat the complicated relations and strong autocorrelation present in the crop production data. 
Panel data is a combination of cross-sectional and time series data. Therefore, using a regression suited to panel data has the advantage of distinguishing between fixed and random effects. Fixed effects, effects that are independent of random disturbances, e.g., observations independent of time. Random effects, effects that include random disturbances. Panel data is more informative since it includes more information, but it has to be modeled correctly by taking into account fixed vs. random effects.

Panel data helps us to controls heterogeneity of cross-section units such as individuals, states, firms, countries etc., over time. Panel data estimation considers all cross-section units as heterogeneous. It helps us to get unbiased estimation. There are time invariant and state invariant variables which we observe or not. As compared to pure cross section and time series, panel data estimation is better to identify and measure effects of independent variables on dependent variables what we cannot measure using time series and cross section data. In addition to this "Panel data give more informative data, more variability, less collinearity among the variables, more degree of freedom and more efficiency". It is also better estimation method to study the duration of economic states and the "dynamics of change", over time. It is a good estimation method to 'construct and test complicated behavioral models', (Baltagi, (2001)).

Based on the above discussion, the present study is aimed to study the trends in food grain production in different states in India over the period 2001-02 to 2020-2021 based on panel regression model.

\section{Materials and Methods}

2.1. Materials: The present investigation was carried out to study the dynamic relationships between area and production and its trends in paddy crop in different districts of Tamil Nadu. The cross-sectional time series data on paddy crop during the period 1998-99 to 2010-2020) have been collected from Reserve Bank of India - Handbook of Statistics on Indian Economy (rbi.org.in).

2.2. Methods: Panel data are a type of data that contain observations of multiple phenomena collected over different time periods for the same group of individuals, units, or entities. In short, econometric panel data are multidimensional data collected over a given period.

A simple panel data regression model is specified as

$$
Y_{i t}=\alpha+\beta X_{i t}+v_{i t}
$$

where $v_{i t}$ are the estimated residuals from the panel regression analysis. Here, $\mathrm{Y}$ is the dependent variable, $\mathrm{X}$ is the independent or explanatory variable, $\alpha$ and $\beta$ are the intercept and slope, $\mathrm{i}$ stands for the $\mathrm{i}^{\text {th }}$ cross-sectional unit and $\mathrm{t}$ for the $\mathrm{t}^{\text {th }}$ month, and $\mathrm{X}$ is assumed to be non-stochastic and the error term to follow classical assumptions, namely, $E\left(v_{i t}\right)=N\left(0, \sigma^{2}\right)$ .In this study, $\mathrm{i}$, the number of cross-sections is $28(\mathrm{i}=1,2,3,4, \ldots, 28)$, and $\mathrm{t}=1,2,3, \ldots$, 22.Detailed discussions of panel data models were given in Hsiao,(2003), Greene, (2008) and Gujarathi, (2017). 
2.2.1. Unit Root Test: Unit roots for the panel data can be tested using either the Leuin-LlinChu, (2002) test or the Hadri, (2000) LM stationarity test. The null hypothesis is that panels contain unit roots, and the alternative hypothesis is that panels are stationary. In the results, if the $\mathrm{p}$ value is less than 0.05 , then one can reject the null hypothesis and accept the alternative hypothesis. Similarly, the unit root for the first difference can also be tested using a similar method.

2.2.2. Constant Coefficients Model: The Constant Coefficients Model (CCM) assumes that all coefficients (intercept and slope) remain unchanged across cross-sectional units, and over time. In other words, the CCM ignores the space and time dimensions of panel data. Put differently, under the CCM, the cross-sectional units are assumed to be homogeneous such that the values of intercept and slope coefficients are same irrespective of cross-sectional unit being considered. Accepting this homogeneity assumption (also called pooling assumption), the CCM uses the panel (or pooled) data set, and applies Ordinary Least Squares (OLS) method to estimate unknown parameters of the model. Thus, the CCM is nothing but straightforward application of OLS to a given panel or pooled data to obtain estimates for unknown parameters of the model (Bhaumik, (2017)).

2.2.3. Individual Specific-Effect Model: Here, it is assumed that there is unobserved heterogeneity across individuals and captured by $\alpha_{i}$. The main question is whether the individual-specific effects $\alpha_{i}$ are correlated with the regressor; if they are correlated, a fixed effects model exists. If these factors are not correlated, a random effects model exists.

\subsubsection{Fixed-Effect OR Least-Square Dummy Variable Regression Model: Fixed effect} regression model indicates that each unit has its own intercept. There will be heterogeneity among the unit due to individual intercepts. Here in fixed effect model the unit intercepts are time-invariant (do not vary over time) even if they might be different among cross section units. However the fixed effect model believes that the coefficients of the independent variables do not vary across cross-section unit or over time.These fixed effects model can be implemented with the dummy variable technique. Therefore, the fixed effects model can be written as

$$
Y_{i t}=\alpha_{1}+\alpha_{2} D_{2 i}+\alpha_{3 i} D_{3 i}+\alpha_{4} D_{4 i}+\ldots+\alpha_{28} D_{28 i}+\beta_{2} X_{i t}+v_{i t}
$$

where $D_{2 i=1}$ if the observation belongs to Cuddalore district and 0 otherwise, $D_{3 i}=1$ if the observation belongs to Dharmapuri 0 otherwise, ${ }^{D_{4 i}=1}$ if the observation belongs to Dindigul and 0 otherwise, and so on. Here, the district Coimbatore is considered the baseline, or reference, category. Thus, the intercept ${ }^{\alpha_{1}}$ represents the intercept value of the Coimbatore district, and the other $\alpha$ coefficients represent how much the intercept values of the other districts differ from the intercept value of the Coimbatore district. Thus, ${ }^{\alpha}$ shows how much the intercept value of the second district, Cuddalore differs from ${ }^{\alpha_{1}}$. The sum $\left({ }_{1}+\alpha_{2}\right)$ gives the actual value of the intercept for Cuddalore The intercept values of the other districts can be computed similarly. 
2.2.5. Random-Effect (RE) Model: Random effects model is also called error component model (ECM). In this model the cross section units will have random intercept instead of fixed intercept. The rationale behind random effects model is that, unlike the fixed effect model, the variation across entities is assumed to be random and uncorrelated with the predictor or independent variables included in the model, the crucial distinction between the fixed and random effects is whether the unobserved individual effects embodies elements that are correlated with regressors in the model, not whether these effects are stochastic or not (Green, 2008). The RE model assumes that individual-specific effects $\alpha_{i}$ are random and one should include $\alpha_{i}$ in the error term. Each cross-section has the same slope parameters and a composite error term. So the model (1) become Random-Effect Model (REM):

$$
\begin{gathered}
y_{i t}=x_{i t} \beta+\left(\alpha_{i}+v_{i t}\right) \\
\text { Let } \varepsilon_{i t}=\alpha_{i}+v_{i t} .
\end{gathered}
$$

Here $\varepsilon_{i t}, \alpha_{i}$ and $v_{i}$ are normally distributed with zero means and constant variances $\sigma_{\varepsilon}^{2}, \sigma_{\alpha}^{2}$ and $\sigma_{v}^{2}$, respectively.

Hence: $\operatorname{var}\left(\varepsilon_{i t}\right)=\sigma_{\alpha}^{2}+\sigma_{v}^{2}$, and $\operatorname{cov}\left(\varepsilon_{i t}, \varepsilon_{i s}\right)=\sigma_{\alpha}^{2}$; therefore, $\rho_{\varepsilon}=\operatorname{cor}\left(\varepsilon_{i t}, \varepsilon_{i s}\right)=\frac{\sigma_{\alpha}^{2}}{\sigma_{\alpha}^{2}+\sigma_{\varepsilon}^{2}}$.

Rho is the interclass correlation of the error or the fraction of the variance in the error term due to individual-specific effects. These variable approaches 1 if individual effects dominate the idiosyncratic error (Bhaumik, (2017)).

2.2.6. Hausman test: The Hausman test (Hasman, 1978) is the standard procedure used in empirical panel data analysis to distinguish between the fixed effects and random effects. In the Hausman test the null hypothesis signifies that there is no significant difference in the estimator of fixed effect model and random effect model. If we reject the null hypothesis the fixed effect model will be the appropriate model. Rejecting the null hypothesis shows that there might be correlation between the error term and dependent variable. The test statistic can be calculated is given as follows:

$$
H=\left(\widehat{\beta}_{R E}-\widehat{\beta}_{F E}\right)^{l}\left(V\left(\widehat{\beta}_{R E}\right)-V\left(\widehat{\beta}_{F E}\right)\right)\left(\widehat{\beta}_{R E}-\widehat{\beta}_{F E}\right)
$$

Here, $\widehat{\beta}_{R E}$ and $\widehat{\beta}_{F E}$ are the vector of parameter estimates of random effect and fixed effect, respectively. Under the null hypothesis, this statistic has asymptotically the Chi-squared distribution with the number of degrees of freedom equal to the rank of the matrix:

$$
\left(V\left(\widehat{\beta}_{R E}\right)-V\left(\widehat{\beta}_{F E}\right)\right)
$$

2.2.7. Wald Test: The Wald test (Wald, 1943) can determine which model variables make significant contributions. The Wald test (also called the Wald chi-squared test) is a way to determine if explanatory variables in a model are significant, meaning that they add something to the model; variables that add nothing can be deleted without affecting the model in a meaningful way. The test can be used for a multitude of different models, including those with binary variables or continuous variables. The null hypothesis for the test is: some parameter $=$ some value. 
2.2.8. Breusch-Pagan Lagrange Multiplier Test: The Breusch-Pagan-Godfrey test (Breusch and Pagan, (1980)) is a Lagrange multiplier test of the null hypothesis of no heteroskedasticity, i.e., constant variance among residuals.

Ho: The null hypothesis of the test states that there is constant variance among residuals.

\section{RESULTS AND DISCUSSIONS}

The results obtained in this paper based on applying different statistical tools related to panel regression models are discussed in sequence below.

\subsection{Unit root tests}

In analyses of time series data, it is important that the study variables are stationary, which means that the means and variances of the variable data are the same. Accordingly, Levin-Lin-Chu unit root tests were carried out to test the stationarity of the study variables, area under the crop (AREA) and the production (PRODN). The results are reported in Tables 1 and 2.

Table 1: Unit root test results for area (AREA) under the Paddy crop

\begin{tabular}{|c|c|c|c|c|c|}
\hline \multicolumn{2}{|c|}{ Individual Effect } & \multicolumn{2}{c|}{ Individual Effect and Trend } & \multicolumn{2}{c|}{ None } \\
\hline Statistic & Prob $^{* *}$ & Statistic & Prob $^{* *}$ & Statistic & Prob $^{* *}$ \\
\hline 6.43486 & 0.0000 & 6.74762 & 0.0000 & 3.54163 & 0.0002 \\
\hline ** Probabilities are computed assuming asymptotic Normality \\
\hline
\end{tabular}

Table 2: Unit root test results for the production (PRODN) of paddy crop

\begin{tabular}{|c|c|c|c|c|c|}
\hline \multicolumn{2}{|c|}{ Individual Effect } & \multicolumn{2}{c|}{ Individual Effect and Trend } & \multicolumn{2}{c|}{ None } \\
\hline Statistic & Prob $^{* *}$ & Statistic & Prob $^{* *}$ & Statistic & Prob $^{* *}$ \\
\hline 7.05042 & 0.0000 & 7.45309 & 0.0000 & 5.85905 & 0.0000 \\
\hline ** Probabilities are computed assuming asymptotic Normality \\
\hline
\end{tabular}

The test results presented in Tables 1 and 2 reveal the two variables under study, NCASE and DEATH, to be stationary in level, since the Levin, Lin and Chu t-statistics are found to be highly significant $(\mathrm{p}<0.0000)$. Hence, the variables under study are found to be stationary.

\subsection{Summary statistics}

The descriptive statistics presented in the Table 3 reveal that district wise area under the Paddy crops are normally distributed in all the districts except Kanchipuram and Tiruvallur districts since Jarque-Bera statistics values were non-significant. Highest area under the crops were registered in Tiruvarur, Thanjavur etc., Very lowest were registered in Coimbatore and Nilgiris districts. The trends in area and production of Paddy crop are depicted in the Fig.1. \& Fig.2 respectively. 
Table 3: Summary Statistics of area under the Paddy crop

\begin{tabular}{|c|c|c|c|c|c|c|c|}
\hline $\begin{array}{l}\text { Sr. } \\
\text { No. }\end{array}$ & Name of District & Sum & Mean & Max. & Min. & S.D. & $\begin{array}{c}\text { Jarque- } \\
\text { Bera } \\
\text { Prob. }\end{array}$ \\
\hline 1. & Coimbatore & 115414 & 5246.09 & 16875 & 680 & 4682.55 & 0.0697 \\
\hline 2. & Cuddalore & 2623811 & 119264.10 & 139987 & 102336 & 11754.78 & 0.4486 \\
\hline 3. & Dharmapuri & 596753 & 27125.14 & 61608 & 3889 & 16546.05 & 0.1299 \\
\hline 4. & Dindigul & 346772 & 15762.36 & 28437 & 1522 & 7160.32 & 0.3840 \\
\hline 5. & Erode & 782060 & 35548.18 & 68130 & 695 & 19277.00 & 0.8635 \\
\hline 6. & Kanchipuram & 2326587 & 105754.00 & 207871 & 61881 & 38303.09 & 0.0030 \\
\hline 7. & Kanyakumari & 416029 & 18910.41 & 32907 & 9628 & 6926.36 & 0.3969 \\
\hline 8. & Karur & 300142 & 13642.82 & 18398 & 3672 & 3378.22 & 0.0562 \\
\hline 9. & Madurai & 1156984 & 52590.18 & 88338 & 10407 & 20807.37 & 0.5518 \\
\hline 10. & Nagapattinam & 3505507 & 159341.20 & 170840 & 136039 & 10061.37 & 0.1351 \\
\hline 11. & Namakkal & 273511 & 12432.32 & 24167 & 2188 & 5954.77 & 0.4685 \\
\hline 12. & Perambalur & 541331 & 24605.95 & 48734 & 2613 & 17761.87 & 0.2296 \\
\hline 13. & Pudukkottai & 1910130 & 86824.09 & 107199 & 67238 & 11054.48 & 0.6272 \\
\hline 14. & Ramanathapuram & 2758053 & 125366.00 & 136902 & 114981 & 5724.71 & 0.2764 \\
\hline 15. & Salem & 570461 & 25930.05 & 48400 & 5024 & 12641.51 & 0.5779 \\
\hline 16. & Sivaganga & 1680160 & 76370.91 & 89924 & 63492 & 8074.29 & 0.5014 \\
\hline 17. & Thanjavur & 3717398 & 168972.60 & 196816 & 123293 & 19728.65 & 0.6061 \\
\hline 18. & Nilgiris & 21311 & 968.68 & 2611 & 32 & 793.84 & 0.3432 \\
\hline 19. & Theni & 318444 & 14474.73 & 21747 & 6210 & 3951.38 & 0.9031 \\
\hline 20. & Tiruvallur & 2030891 & 92313.23 & 140703 & 66734 & 16295.10 & 0.0041 \\
\hline 21. & Tiruvarur & 3733186 & 169690.40 & 194743 & 121437 & 19236.23 & 0.1810 \\
\hline 22. & Thoothukudi & 349981 & 15908.23 & 22709 & 4808 & 4694.22 & 0.3502 \\
\hline 23. & Trichirappalli & 1296383 & 58926.50 & 79576 & 27068 & 13390.18 & 0.9956 \\
\hline 24. & Tirunelveli & 1690797 & 76854.41 & 98506 & 29881 & 17281.57 & 0.0548 \\
\hline 25. & Tiruvannamalai & 2375224 & 107964.70 & 161709 & 43872 & 29809.74 & 0.9282 \\
\hline 26. & Vellore & 987726 & 44896.64 & 77109 & 26287 & 11447.83 & 0.1536 \\
\hline 27. & Viluppuram & 3122606 & 141936.60 & 182303 & 75279 & 29396.23 & 0.1762 \\
\hline 28. & Virudhunagar & 579368 & 26334.91 & 34953 & 13826. & 5842.06 & 0.4247 \\
\hline
\end{tabular}






Fig.1: Trends in Area under the Paddy crop

Table 4: Summary statistics for Paddy crop production

\begin{tabular}{|c|l|c|c|c|c|c|c|}
\hline $\begin{array}{c}\text { Sr. } \\
\text { No. }\end{array}$ & Name of District & Sum & Mean & Max. & Min. & S.D. & $\begin{array}{c}\text { Jarque- } \\
\text { Bera } \\
\text { Prob. }\end{array}$ \\
\hline 1. & Coimbatore & 429818 & 19537.18 & 60494 & 2326 & 16443.40 & 0.0859 \\
\hline 2. & Cuddalore & 8771665 & 398712.00 & 641958 & 218345 & 118217.90 & 0.9159 \\
\hline 3. & Dharmapuri & 2245912 & 102086.90 & 227438 & 17025 & 58567.46 & 0.3357 \\
\hline 4. & Dindigul & 1462684 & 66485.64 & 118998 & 4506 & 29903.17 & 0.7592 \\
\hline 5. & Erode & 3407341 & 154879.10 & 306471 & 1568 & 79742.41 & 0.6008 \\
\hline 6. & Kanchipuram & 8619116 & 391778.00 & 711233 & 278087 & 114038.30 & 0.0086 \\
\hline 7. & Kanyakumari & 1765023 & 80228.32 & 143642 & 33034 & 29248.21 & 0.6233 \\
\hline 8. & Karur & 1089394 & 49517.91 & 69898 & 10792 & 14312.75 & 0.1752 \\
\hline 9. & Madurai & 4474860 & 203402.70 & 331342 & 34120 & 87674.52 & 0.5475 \\
\hline 10. & Nagapattinam & 8788465 & 399475.70 & 630607 & 136637 & 169431.40 & 0.3525 \\
\hline 11. & Namakkal & 1159115 & 52687.05 & 105619 & 7133 & 26345.87 & 0.5688 \\
\hline 12. & Perambalur & 1706031 & 77546.86 & 164567 & 9439 & 47849.37 & 0.4684 \\
\hline 13. & Pudukkottai & 5069817 & 230446.20 & 368902 & 73659 & 79133.99 & 0.7713 \\
\hline 14. & Ramanathapuram & 4133352 & 187879.60 & 471001 & 244 & 143349.80 & 0.4918 \\
\hline 15. & Salem & 2350945 & 106861.10 & 204300 & 18415 & 51924.89 & 0.7386 \\
\hline 16. & Sivaganga & 3246373 & 147562.40 & 310176 & 41283 & 76099.80 & 0.7291 \\
\hline 17. & Thanjavur & 12171223 & 553237.40 & 831483 & 318325 & 147642.60 & 0.4881 \\
\hline
\end{tabular}




\begin{tabular}{|l|l|c|c|c|c|c|c|}
\hline 18. & Nilgiris & 74483 & 3385.59 & 9192 & 150 & 2651.01 & 0.3592 \\
\hline 19. & Theni & 1418410 & 64473.18 & 80292 & 36668 & 14752.21 & 0.2835 \\
\hline 20. & Tiruvallur & 7341596 & 333708.90 & 484861 & 195536 & 82330.56 & 0.6577 \\
\hline 21. & Tiruvarur & 10413521 & 473341.90 & 852925 & 112183 & 231344.00 & 0.4561 \\
\hline 22. & Thoothukudi & 1484443 & 67474.68 & 108163 & 15683 & 22266.58 & 0.6769 \\
\hline 23. & Trichirappalli & 5093080 & 231503.60 & 309928 & 76591 & 60909.63 & 0.1738 \\
\hline 24. & Tirunelveli & 7213127 & 327869.40 & 488445 & 105193 & 87059.67 & 0.3692 \\
\hline 25. & Tiruvannamalai & 8267609 & 375800.40 & 704247 & 115453 & 138544.10 & 0.8328 \\
\hline 26. & Vellore & 3772874 & 171494.30 & 263941 & 89863 & 46508.35 & 0.9286 \\
\hline 27. & Viluppuram & 11514713 & 523396.00 & 832585 & 234750 & 156740.30 & 0.8697 \\
\hline 28. & Virudhunagar & 1897842 & 86265.55 & 158214 & 15883 & 30326.26 & 0.7807 \\
\hline
\end{tabular}

a

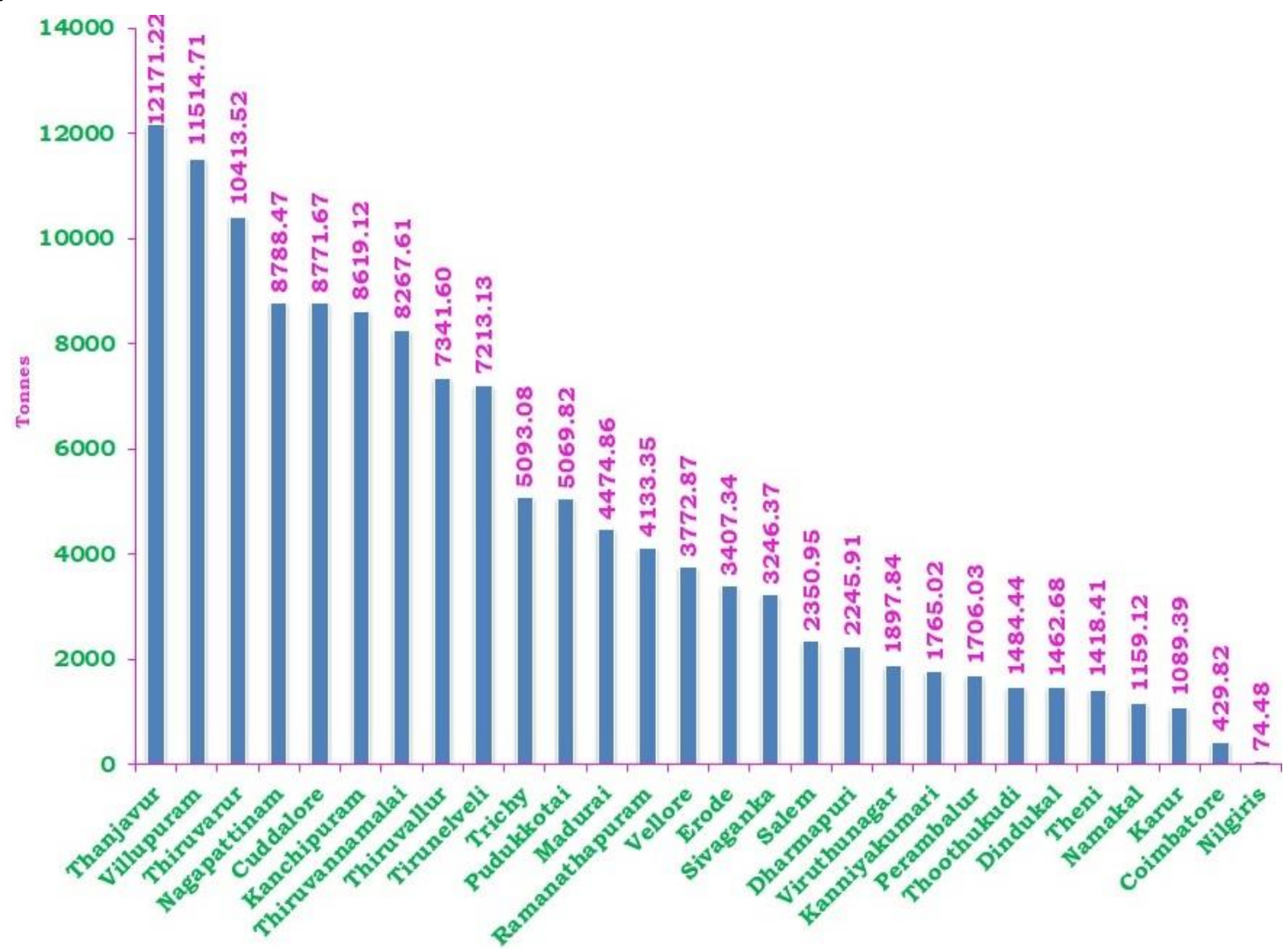

Fig.2. Trends in Paddy crop production

\subsection{Variations between districts}

To determine the variations across districts, ANOVA tests were carried out individually for each of the study variables, AREA and PRODN, and the results are presented in Tables 5 and 6. 
Table 5: Results of test for equality of means of number of COVID-19 infections.

\begin{tabular}{lrrr}
\hline Method & df & Value & Probability \\
\hline Anova F-test & $(27,588)$ & 251.3787 & 0.0000 \\
Welch F-test* & $(27,206)$ & 911.7723 & 0.0000 \\
\hline
\end{tabular}

*Test allows for unequal cell variances

Analysis of Variance

\begin{tabular}{lrrr}
\hline Source of Variation & df & Sum of Sq. & Mean Sq. \\
\hline Between & 27 & $1.72 \mathrm{E}+12$ & $6.38 \mathrm{E}+10$ \\
Within & 588 & $1.49 \mathrm{E}+11$ & $2.54 \mathrm{E}+08$ \\
\hline Total & 615 & $1.87 \mathrm{E}+12$ & $3.04 \mathrm{E}+09$ \\
\hline
\end{tabular}

Table 6: Results of test for equality of means of number of deaths due to COVID-19.

\begin{tabular}{lrrr}
\hline Method & df & Value & Probability \\
\hline Anova F-test & $(27,588)$ & 64.51287 & 0.0000 \\
Welch F-test* & $(27,204.955)$ & 147.5820 & 0.0000
\end{tabular}

*Test allows for unequal cell variances

Analysis of Variance

\begin{tabular}{lrrr}
\hline Source of Variation & df & Sum of Sq. & Mean Sq. \\
\hline Between & 27 & $1.58 \mathrm{E}+13$ & $5.87 \mathrm{E}+11$ \\
Within & 588 & $5.35 \mathrm{E}+12$ & $9.09 \mathrm{E}+09$ \\
\hline Total & 615 & $2.12 \mathrm{E}+13$ & $3.45 \mathrm{E}+10$ \\
\hline
\end{tabular}

The results reveal that since the ANOVA tests are highly significant $(\mathrm{p}<0.0000)$ for both study variables, highly significant variations occur between the districts.

\subsection{Pooled OLS regression or constant coefficients model}

The panel least squares method is employed with production (PRODN) as the dependent variable and the area (AREA) under the paddy crop as the independent variable. The regression results based on EViews, Version 11, are presented in Table 7.

Table 7: Results of pooled OLS Regression or Constant Coefficients Model

\begin{tabular}{lrlrr}
\hline \multicolumn{1}{c}{ Variable } & Coefficient & Std. Error & t-Statistic & \multicolumn{1}{c}{ Prob. } \\
\hline \multicolumn{1}{c}{ C } & 17985.55 & 5580.043 & 3.223191 & 0.0013 \\
\multicolumn{1}{c}{ AREA } & 2.948231 & 0.065388 & 45.08822 & 0.0000 \\
\hline Root MSE & 89320.98 & R-squared & & 0.768035 \\
Mean dependent var & 210037.1 & Adjusted R-squared & & 0.767657 \\
S.D. dependent var & 185607.2 & S.E. of regression & & 89466.34 \\
Akaike info criterion & 25.64435 & Sum squared resid & & $4.91 \mathrm{E}+12$ \\
Schwarz criterion & 25.65872 & Log likelihood & & -7896.461 \\
Hannan-Quinn criter. & 25.64994 & F-statistic & & 2032.948 \\
Durbin-Watson stat & 0.965869 & Prob(F-statistic) & & 0.000000 \\
\hline
\end{tabular}


The results reveal that the intercept and slopes are very highly significant, and the model F-statistic is also highly significant, with an exceedingly high $\mathrm{R}^{2}$ of $77 \%$. This assures the production of paddy crops where significantly influenced by the area under the paddy crop. Every unit increases in area the production would be increased by $3 \%$.

\subsection{FE least squares dummy variable (LSDV) model}

The results presented in Table 8 reveal that the FE model is highly significant, with a high R2 of $87 \%$. The slope coefficient for the area under the paddy crop was found to be highly significant, which shows that the area under the paddy crop played an important role in variation in paddy production The dummy variables for Dharmapuri, Namakkal, Ramanathapuram, Salem, Thanjavur, Nilgiris, Tiruvarur, Thoothukudi, Vellore and Virudhunagar were found to be very highly significant, suggesting that perhaps these district variations were heterogeneous; therefore, the pooled regression model values might not be informative. Additionally, the values of the slope coefficients in Table 6 were also different, again casting some doubt in the results in Table 5. Additionally, if the Durbin-Watson d value was nearer to 2, there was no autocorrelation in the FE model. It seems that the FE model have found better than the pooled regression model.

Table 8: Results of FE or LSDV regression model.

\begin{tabular}{|c|c|c|c|c|}
\hline Coefficient & Estimates & Std. Error & t-Statistic & Prob. \\
\hline $\mathrm{C}(1)$ & -2551.651 & 14491.43 & -0.176080 & 0.8603 \\
\hline $\mathrm{C}(2)$ & 4.210532 & 0.175582 & 23.98037 & 0.0000 \\
\hline $\mathrm{C}(3)$ & -100901.8 & 28619.73 & -3.525601 & 0.0005 \\
\hline $\mathrm{C}(4)$ & -9572.692 & 20810.18 & -0.460000 & 0.6457 \\
\hline $\mathrm{C}(5)$ & 2669.353 & 20535.71 & 0.129986 & 0.8966 \\
\hline $\mathrm{C}(6)$ & 7754.034 & 21133.24 & 0.366912 & 0.7138 \\
\hline $\mathrm{C}(7)$ & -50950.75 & 27013.65 & -1.886111 & 0.0598 \\
\hline $\mathrm{C}(8)$ & 3157.088 & 20592.77 & 0.153311 & 0.8782 \\
\hline $\mathrm{C}(9)$ & -5373.961 & 20505.60 & -0.262073 & 0.7934 \\
\hline $\mathrm{C}(10)$ & -15478.26 & 22077.33 & -0.701093 & 0.4835 \\
\hline $\mathrm{C}(11)$ & -268884.0 & 33916.88 & -7.927734 & 0.0000 \\
\hline $\mathrm{C}(12)$ & 2892.024 & 20491.41 & 0.141133 & 0.8878 \\
\hline $\mathrm{C}(13)$ & -23505.64 & 20733.08 & -1.133726 & 0.2574 \\
\hline $\mathrm{C}(14)$ & -132577.7 & 24969.45 & -5.309598 & 0.0000 \\
\hline $\mathrm{C}(15)$ & -337426.4 & 29379.15 & -11.48524 & 0.0000 \\
\hline $\mathrm{C}(16)$ & 233.5037 & 20772.47 & 0.011241 & 0.9910 \\
\hline $\mathrm{C}(17)$ & -171448.1 & 23963.78 & -7.154468 & 0.0000 \\
\hline $\mathrm{C}(18)$ & -155675.6 & 35280.66 & -4.412492 & 0.0000 \\
\hline $\mathrm{C}(19)$ & 1858.577 & 20466.31 & 0.090812 & 0.9277 \\
\hline $\mathrm{C}(20)$ & 6078.532 & 20516.62 & 0.296274 & 0.7671 \\
\hline $\mathrm{C}(21)$ & -52427.23 & 25534.53 & -2.053189 & 0.0405 \\
\hline $\mathrm{C}(22)$ & -238593.4 & 35383.43 & -6.743083 & 0.0000 \\
\hline $\mathrm{C}(23)$ & 3044.235 & 20538.03 & 0.148224 & 0.8822 \\
\hline
\end{tabular}




\begin{tabular}{|c|c|c|c|c|}
\hline \multicolumn{1}{|c|}{$\mathrm{C}(24)$} & -14056.62 & 22519.83 & -0.624189 & 0.5327 \\
\hline $\mathrm{C}(25)$ & 6823.118 & 24008.13 & 0.284200 & 0.7764 \\
\hline $\mathrm{C}(26)$ & -76236.87 & 27268.82 & -2.795753 & 0.0053 \\
\hline $\mathrm{C}(27)$ & -14992.80 & 21604.96 & -0.693951 & 0.4880 \\
\hline $\mathrm{C}(28)$ & -71681.04 & 31532.97 & -2.273210 & 0.0234 \\
\hline $\mathrm{C}(29)$ & -22066.78 & 20785.01 & -1.061668 & 0.2888 \\
\hline Root MSE & 66217.38 & R-squared & 0.872515 \\
\hline Mean dependent var & 210037.1 & Adjusted R-squared & 0.866434 \\
\hline S.D. dependent var & 185607.2 & S.E. of regression & 67833.36 \\
\hline Akaike info criterion & 25.13343 & Sum squared resid & $2.70 \mathrm{E}+12$ \\
\hline Schwarz criterion & 25.34167 & Log likelihood & -7712.096 \\
\hline Hannan-Quinn criter. & 25.21440 & F-statistic & 143.4805 \\
\hline Durbin-Watson stat & 1.584903 & Prob(F-statistic) & 0.000000 \\
\hline
\end{tabular}

\subsection{Wald test}

To determine whether the FE model or pooled OLS regression model is more suitable, we adopt the Wald test. Here, the null hypothesis is that the pooled OLS regression model is appropriate (all dummy variables equal zero), and the alternative hypothesis is that the FE model is appropriate (all dummy variables do not equal zero). Accordingly, the Wald test is carried out and presented in Table 9.

Table 9: Characteristics of Wald test

\begin{tabular}{lccc}
\hline Test Statistic & Value & df & Probability \\
\hline F-statistic & 18.46420 & $(26,587)$ & 0.0000 \\
Chi-square & 480.0693 & 26 & 0.0000 \\
\hline
\end{tabular}

The Wald test F-statistic is found to be highly significant $(\mathrm{p}<0.0000)$, indicating that the FE or LSDV regression model is more appropriate than the panel pooled regression model. Not all dummy variables are not equal to zero.

\subsection{RE model}

The RE model is employed, by keeping the paddy crop production as the dependent variable and the area under the paddy crop as the independent variable, and the test results are presented in Table 10.

Table 10: Characteristics of Fitted RE model

\begin{tabular}{crrrc}
\hline Variable & Coefficient & Std. Error & t-Statistic & Prob. \\
\hline C & -27256.39 & 14097.69 & -1.933394 & 0.0536 \\
AREA & 3.642751 & 0.134417 & 27.10045 & 0.0000 \\
\hline \multicolumn{5}{c}{ Effects Specification } \\
\hline Cross-section random & & S.D. & Rho \\
Idiosyncratic random & & 66647.82 & 0.4109 \\
\hline
\end{tabular}

\section{Weighted Statistics}




\begin{tabular}{lclr}
\hline Root MSE & 69048.21 & R-squared & 0.535030 \\
Mean dependent var & 51955.77 & Adjusted R-squared & 0.534273 \\
S.D. dependent var & 101342.8 & S.E. of regression & 69160.57 \\
Sum squared resid & $2.94 \mathrm{E}+12$ & F-statistic & 706.5166 \\
Durbin-Watson stat & 1.507303 & Prob(F-statistic) & 0.000000 \\
\hline & \multicolumn{2}{c}{ Unweighted Statistics } & 210037.1 \\
\hline R-squared & 0.725413 & Mean dependent var & 0.760925 \\
Sum squared resid & $5.82 \mathrm{E}+12$ & Durbin-Watson stat &
\end{tabular}

The results presented in Table 10 reveal that the RE model explains only $54 \%$ of the variation in the Paddy crop production in relation to the area under the Paddy crop. The rho value is 0.4109 , which indicates that the individual effects of the cross-sections are $0.4 \%$.

\subsection{Hausman test}

The results presented in Table 11 reveal that the Hausman test statistic is significant and that the null hypothesis is rejected, indicating that the FE model is an appropriate model. A remarkably high $\mathrm{R}^{2}$ value of $80 \%$ is noted in the Hausman test. This finding supports the rejection of the null hypothesis that the random effect model is appropriate. Additionally, in the last row of Table 9, the FE and RE coefficient values of the regressor variable are found to be highly statistically significant.

Table 11: Hausman test results (Test cross-section random effects).

\begin{tabular}{|c|c|c|c|c|}
\hline Test Summary & & hi-Sq.tatistic & Chi-Sq. d.f. & Prob. \\
\hline Cross-section random & & 25.261800 & 1 & 0.0000 \\
\hline \multicolumn{5}{|c|}{ Cross-section random effects test comparisons: } \\
\hline Variable & Fixed & Random & Var(Diff.) & Prob. \\
\hline AREA & 4.210532 & 3.642751 & 0.012761 & 0.0000 \\
\hline Variable & Coefficient & Std. Error & t-Statistic & Prob. \\
\hline $\mathrm{C}$ & -64242.34 & 11759.67 & -5.462936 & 0.0000 \\
\hline AREA & 4.210532 & 0.175582 & 23.98037 & 0.0000 \\
\hline \multicolumn{5}{|c|}{ Effects Specification } \\
\hline Root MSE & 66217.38 & R-squared & & 0.872515 \\
\hline Mean dependent var & 210037.1 & Adjusted R-squared & & 0.866434 \\
\hline S.D. dependent var & 185607.2 & S.E. of regression & & 67833.36 \\
\hline Akaike info criterion & 25.13343 & Sum squared resid & & $2.70 \mathrm{E}+12$ \\
\hline Schwarz criterion & 25.34167 & Log likelihood & & -7712.096 \\
\hline Hannan-Quinn criter. & 25.21440 & F-statistic & & 143.4805 \\
\hline Durbin-Watson stat & 1.584903 & Prob(F-statistic) & & 0.000000 \\
\hline
\end{tabular}

\section{CONCLUSION}

The pooled regression model was not found suitable to study the relationship between the area under the paddy crop and it's production. The panel regression fixed effect model was emerged as an appropriate model and it explained $87 \%$ variations in paddy crop production. 


\section{REFERENCES}

[1] Baltagi, B.H., "Econometric Analysis of Panel Data”, $6^{\text {th }}$ Edition, Wiley, New York, NY, https://link.springer.com/book/10.1007\%2F978-3-030-53953-5, (2021).

[2] Bhamik, S.K., "Principles of Econometrics", 2nd edition, Oxford University Press, (2017).

[3] Breusch, T., and A. Pagan, "the Lagrange Multiplier Test and its Application to Model Specification in Econometrics”, Review of Economic Studies, 47, (1980), pp.239-253.

[4] Greene, W.H., "Econometric Analysis”, 2008, Pearson Prentice Hall, Upper Saddle River, NJ, (2008).

[5] Gujarati, D.N., D.C.Porter and G.Sangeetha, "Basic Econometrics", 5th edition. McGraw Hill Education, New York, NY, (2017).

[6] Hadri, K., “Testing for Units Roots in Heterogeneous Panel Data”. Econometrics Journal, 3, (2000), pp.148-161.

[7] Hausman, J. A., "Specification Tests in Econometrics", Econometrica, 46, (1978), pp.1251-1272.

[8] Hsiao, C., "Analysis of Panel Data. Cambridge University Press", Cambridge, (2003).

[9] Levin, A., C.F. Lin, and C.S.J.Chu, "Unit Root Tests in Panel Data: Asymptotic and Finite-Sample Properties”, Journal of Econometrics, 108, (2002), pp.1-24.

[10] Wald,A, "Test of statistical hypotheses concerning several parameters when the number of observations is large”, Transactions of the American Mathematical Society, 54, (1943), pp.426-482, http://www.jstor.org/stable/1990256.

[11] Zaefizadah M., Khayatnezhad M., and Ghlaomin M., "Comparison of Multiple Linear Regression (MLR) and Artificial Neural Network (ANN) in Predicting the Yield Using its Components in the Hulless Barley", J. Agriculture and Environmental Sciences, 10(1), (2011), pp.60-64. 